\title{
Pengelolaan Wisata Kampung Blekok Sebagai Upaya Peningkatan Ekonomi Masyarakat Berbasis Community-based Tourism Kabupaten Situbondo
}

\author{
Ayu Wanda Febrian ${ }^{1, *}$ dan Yunita Suresti ${ }^{2}$ \\ ${ }^{1}$ Politeknik Negeri Banyuwangi, Banyuwangi, Indonesia \\ ${ }^{2}$ Politeknik Negeri Banyuwangi, Banyuwangi, Indonesia \\ *Email: ayuwandafebrian@,gmail.com
}

\begin{abstract}
This research was conducted in the village of Blekok Tourism aims to know the management of community-based tourism (CBT) in the village of Blekok Tourism, the way to improve the community's economy and economic impacts and to estimate the negative impact of the CBT. Research design is a qualitative descriptive study with data collection techniques using observation, interview and documentation. Data analysis techniques using the Miles and Huberman model. Data validity inspection techniques using triangulation methods. The results showed that the implementation of CBT in several aspects is planning, implementation, management, supervision and evaluation but the implementation is not optimal. As for the addition of applications with the concept of CBT, the management of Pokdarwis, human resources development, local hospitality and the creation of community craftsmen. The way to improve the Community economy in accordance with CBT concept is the event involving the community, maintaining the waste bank program, and cooperation with third parties. The positive impact on the village tourism Object Blekok is, the opening of jobs, increasing public income, utilization of tourism facilities by local communities, help bear the burden of development and multiplier effect. The negative impact of the return on investment capital is uncertain and the desire to benefit individually. Negative impact response is done by evaluation and minimizing through problem solving.
\end{abstract}

\begin{abstract}
Abstraksi: Penelitian ini dilakukan di Wisata Kampung Blekok bertujuan untuk mengetahui pengelolaan berbasis community-based tourism (CBT) di wisata Kampung Blekok, cara yang dilakukan untuk peningkatan ekonomi masyarakat dan dampak ekonomi serta menganggulangi dampak negatif sesuai dengan CBT. Desain penelitian adalah penelitian deskriptif kualitatif dengan teknik pengumpulan data observasi, wawancara, dan dokumentasi. Teknik analisis data menggunakan analisis data model Miles dan Huberman. Teknik pemeriksaan keabsahan data menggunakan metode triangulasi. Ditemukan bahwa penerapan CBT terdapat dalam beberapa aspek yaitu perencanaan, pelaksanaan, pengelolaan, pengawasan dan evaluasi namun pelaksanaannya belum optimal. Adapun penambahan penerapan dengan konsep CBT yaitu manajemen Pokdarwis, Pengembangan sumberdaya manusia, ramah tamah penduduk lokal dan pembentukan komunitas pengrajin. Cara untuk peningkatan ekonomi masyarakat sesuai konsep CBT yaitu event yang melibatkan masyarakat, mempertahankan program bank sampah, dan kerjasama dengan pihak ketiga. Dampak positif di Objek Wisata Kampung Blekok yaitu, terbukanya lapangan pekerjaan, peningkatan pendapatan masyarakat, pemanfaatan fasilitas pariwisata oleh masyarakat lokal, membantu menanggung beban pembangunan dan multiplier effect. Dampak negatif yaitu waktu pengembalian modal investasi tidak pasti dan adanya keinginan untuk mendapatkan keuntungan secara individual. Penanggulangan dampak negatif dilakukan dengan evaluasi dan meminimalisir melalui problem solving.
\end{abstract}

Keywords: Community-based tourism; management; economic enhancement

\section{Pendahuluan}

Tren otonomi daerah mulai mengemuka sejak pengesahan Undang-Undang Nomor 22 Tahun 1999 tentang Pemerintah Daerah. Seiring dengan berjalannya waktu kini Indonesia telah merubah sistem ekonomi dari sistem sentralisasi ke sistem desentralisasi. Diberlakukannya sistem tersebut memberikan peluang besar kepada pemerintah daerah untuk mengembangkan serta memajukan daerahnya terutama pada sektor pariwisata. Salah satu daerah yang memanfaatkan kebijakan ini adalah Kabupaten Situbondo. Tren pariwisata yang semakin bergerak kearah positif menjadikan sektor pariwisata dianggap sebagai sektor yang paling potensial dalam penerimaan pendapatan asli daerah. Oleh karena itu, sektor pariwisata dimanfaatkan oleh pemerintah daerah Kabupaten Situbondo guna meningkatkan perekonomian dan kesejahteraan masyarakat. 
Community-based tourism adalah kepariwisataan berbasis masyarakat ditandai dengan adanya partisipasi masyarakat mulai dari proses perencanaan, penyelenggaraan atau pelaksanaan, dan pengawasan dan pemanfaatan hasil yang diperoleh (Sunaryo, 2013). Lebih lanjut Sunaryo (2013) menerangkan bahwa masyarakat lokal yang akan membangun, memiliki dan mengelola langsung fasilitas wisata serta pelayanannya. Masyarakat diharapkan mampu meningkatkan perekonomian serta mampu melestarikan lingkungan sekitarnya.

Wisata Kampung Blekok merupakan wisata baru yang dikembangkan di Desa Klatakan, Kecamatan Kendit, Kabupaten Situbondo. Wisata ini dikembangkan melalui konsep ekowisata berbasis community-based tourism. Hal ini dikarenakan, area konservasi mangrove seluas kurang lebih 6 hektar ini merupakan tempat hidup dari burung blekok dengan beragam spesies. Desa tempat wisata ini juga merupakan sentra kerajinan tangan berbahan dasar kayu. Melihat potensi wisata ini mendorong pemerintah daerah untuk mengembangkan sebagai salah satu tujuan wisata di Kabupaten Situbondo. Pengelolaan wisata ini dinaungi oleh kelompok sadar wisata (Pokdarwis). Adapun harapan besar dari Pokdarwis yang menginginkan pembangunan objek wisata dapat memberikan manfaat bagi masyarakat. Menyadari hal tersebut diperlukan pula keterlibatan masyarakat agar dapat berkesinambungan dengan visi dari Pokdarwis. Masyarakat sekitar Kampung Blekok sebagian besar bekerja sebagai pengrajin berbahan dasar kayu dan kerang.

Pengembangan destinasi wisata merupakan tahap awal dalam memajukan destinasi wisata. Masyarakat merupakan pelaku utama dari tiap tahap pembangunan. Mulai dari perencanaan, pelaksanaan, pengelolaan, serta evaluasi (Demartoto, 2008). Sehingga, masyarakat serta kelestarian alam memiliki peranan penting dalam mengembangkan dan mengelola suatu destinasi wisata. Keberhasilan wisata ditentukan oleh kesiapan masyarakat serta keterlibatan masyarakat sekitar, namun dalam realita banyak ditemukan wisata yang dalam pengelolaannya tidak melibatkan masyarakat sekitar. Hal ini dikhawatirkan dapat mengakibatkan wisata tidak berkembang secara optimal dan justru akan terbengkalai. Pola interaksi antara kepariwisataan dan lingkungan dapat menimbulkan dampak. Dampak ini terdiri dari dampak positif dan negatif. Apabila suatu destinasi wisata tidak dikembangkan dengan konsep pengelolaan yang tepat, maka dapat menimbulkan dampak negatif yang dapat merusak wisata itu sendiri. Untuk itu, dibutuhkan kajian atas pengelolaan yang tepat untuk diterapkan di wisata Kampung Blekok. Hal ini sebagai jembatan dalam mempertahankan dampak positif yang timbul dari adanya aktivitas wisata, serta menyusun pengelolaan wisata secara struktural guna menanggulangi dan meminimalisir adanya dampak negatif di area wisata.

Adapun tujuan diadakannya penelitian ini yaitu untuk mendeskripsikan pengelolaan berbasis community-based tourism yang sudah diterapkan dan penerapan CBT yang harus diterapkan di Objek Wisata Kampung Blekok, untuk mendeskripsikan cara yang harus dilakukan untuk peningkatan ekonomi masyarakat sesuai dengan konsep CBT dan untuk mendeskripsikan dampak ekonomi yang timbul di objek wisata serta penanggulangan dampak negatif sesuai dengan CBT.

\section{Kajian Pustaka}

\section{Pembangunan Pariwisata Berkelanjutan}

Berdasarkan Undang-Undang RI Nomor 10 Tahun 2009 Tentang Kepariwisataan Pasal 1 Ayat 3 menyatakan bahwa "pariwisata adalah berbagai macam kegiatan wisata dan didukung berbagai fasilitas serta layanan yang disediakan oleh masyarakat, pengusaha, pemerintah dan pemerintah daerah".

World Tourism Organization (2002) mendefinisikan "pariwisata berkelanjutan merupakan sebuah proses dan sistem pengembangan pariwisata yang bisa menjamin keberlangsungan atau keberadaan sumber daya alam dan kehidupan sosial budaya serta memberikan manfaat ekonomi kepada generasi yang akan datang guna memberantas atau mengentaskan kemiskinan". Gortazar, et al. (1999) menyatakan bahwa ada tiga hal yang menjadi penekanan khusus pada pariwisata 
berkelanjutan yaitu pelestarian warisan alam dan budaya serta tradisi masyarakat lokal dan mengurangi konteks yang intensif dan massal terhadap objek-objek wisata budaya; pengurangan dampak-dampak negatif yang ditimbulkan sehubungan dengan pengembangan pariwisata; dan pemberdayaan masyarakat lokal untuk mempertinggi kehidupan sosial dan budayanya guna meningkatkan kualitas dan standar hidup masyarakat lokal.

Terdapat beberapa prinsip pariwisata berkelanjutan dan berwawasan lingkungan sebagaimana dikemukakan oleh Mathieson dan Wall (dalam Sunaryo, 2013) yaitu: aspek indikator lingkungan fisik yaitu kesehatan, kualitas dan kelestarian lingkungan; aspek sosial budaya yaitu manfaat dan sosial ekuitas; dan aspek indikator ekonomi yaitu kepuasan wisatawan, masyarakat dan perusahaan

\section{Potensi dan Daya Tarik Wisata}

Potensi wisata mengacu kepada berbagai sumberdaya yang ada di suatu daerah tertentu yang dapat dikembangkan menjadi daya tarik wisata. Dengan demikian, potensi wisata merupakan sumberdaya-sumberdaya yang dimiliki oleh suatu tempat dan dapat dikembangkan menjadi suatu atraksi wisata (tourist attraction) yang dimanfaatkan untuk kepentingan ekonomi dengan tetap memperhatikan aspek-aspek lainnya (Pendi dalam Sitaresmi, 2011).

Sunaryo (2013) menjelaskan daya tarik wisata merupakan potensi yang menjadi pendorong kehadiran wisatawan ke suatu daerah. Daya tarik wisata tersebut dikelompokkan menjadi tiga golongan yaitu daya tarik wisata alam, daya tarik wisata budaya, dan aya tarik wisata minat khusus.

\section{Pengelolaan Pariwisata}

Pitana \& Diarta (2009) memaparkan pengelolaan (manajemen) adalah seperangkat peranan yang dilakukan oleh seseorang atau sekelompok orang atau bisa juga merujuk kepada fungsi-fungsi yang melekat pada peran tersebut. Fungsi manajemen tersebut meliputi perencanaan, investor, pelaksanaan, pengelolaan dan evaluasi. Pengelolaan wisata merupakan kegiatan untuk mencapai tujuan pariwisata yang berkelanjutan baik secara ekonomi, sosial- budaya, dan lingkungan maka pengelola wajib melakukan manajemen sumber daya efektif. Pengelolaan harus memperhatikan prinsip-prinsip sebagai berikut: (1) Pembangunan dan pengembangan pariwisata harus didasarkan pada kearifan lokal dan special local sense yang merefleksikan keunikan peninggalan budaya dan keunikan lingkungan; (2) Preservasi, proteksi dan peningkatan kualitas sumber daya yang menjadi basis pengembangan kawasan pariwisata; (3) Pengembangan atraksi wilayah tambahan yang mengakar pada khasanah budaya local; (4) Pelayanan kepada wisatawan yang berbasis keunikan budaya dan lingkungan local; (5) Memberikan dukungan dan legitimasi pada pembangunan dan pengembangan pariwisata jika terbukti memberi manfaat positif, tetapi sebaliknya mengendalikan dan menghentikan aktivitas pariwisata tersebut jika melampaui ambang batas (carrying capacity) lingkungan alam atau akseptabilitas sosial walaupun di sisi lain mampu meningkatkan pendapatan masyarakat.

\section{Community-based Tourism}

Suansri (2003) mendefinisikan community-based tourism sebagai pariwisata yang memperhitungkan aspek keberlanjutan lingkungan, sosial dan budaya. Adapun beberapa prinsip dasar community-based tourism yang di sampaikan Suansri (2003) antara lain sebagai berikut: (1) Mengakui, mendukung dan mengembangkan kepemilikan dalam industri pariwisata; (2) Mengikutsertakan anggota komunitas dalam memulai setiap aspek; (3) Mengembangkan kebanggaan komunitas; (4) Mengembangkan kualitas hidup komunitas; (5) Menjamin keberlanjutan lingkungan; (6) Mempertahankan keunikan karakter dan budaya di area local; (7) Membantu berkembangnya pembelajaran tentang pertukaran budaya pada komunitas; (8) Menghargai perbedaan budaya dan martabat manusia; (9) Mendistribusikan keuntungan secara adil pada anggota komunitas; (10) Berperan dalam menentukan persentase pendapatan (pendistribusian pendapatan) dalam proyek yang ada di komunitas. Sepuluh prinsip dasar di atas dapat dijadikan sebagai dasar dalam pengelolaan pariwisata guna 
terwujudnya pembangunan pariwisata berkelanjutan.

Suansri (2003) menyebutkan aspek utama dalam pengembangan community-based tourism dalam 5 dimensi antara lain sebagai berikut dimensi ekonomi, dimensi social, dimensi budaya, dimensi lingkungan, dan dimensi politik.

\section{Dampak Pariwisata}

Dampak pariwisata adalah perubahan-perubahan yang terjadi terhadap lingkungan hidup sebelum adanya kegiatan pariwisata dan setelah adanya kegiatan pariwisata baik langsung maupun tidak langsung yang berupa dampak fisik dan non fisik (Pitana dan Gayatri, 2005). Dampak ekonomi dalam pembangunan pariwisata adalah dampak negatif atau dampak positif yang terjadi terhadap lingkungan ekonomi dalam kehidupan masyarakat sebagai akibat perkembangan pariwisata (Sukadjo, 1997).

Pitana dan Diarta (2009) ada banyak dampak positif pariwisata bagi perekonomian, di antaranya sebagai berikut pendapatan dari penukaran valuta asing, menyehatkan neraca luar negeri, pendapatan dari usaha atau bisnis pariwisata, pendapatan pemerintah, penyerapan tenaga kerja, multiplier effects, dan emanfaatan fasilitas pariwisata oleh masyarakat lokal.

Selain itu, dampak negatif pariwisata di antaranya adalah sebagai berikut: ketergantungan terlalu besar terhadap pariwisata; meningkatkan angka inflasi dan meroketnya harga tanah; meningkatnya kecenderungan untuk mengimpor bahanbahan yang diperlukan dalam pariwisata sehingga produk lokal tidak terserap; sifat pariwisata yang musiman, tidak dapat diprediksi dengan tepat, menyebabkan pengembalian modal investasi juga tidak pasti waktunya; dan timbulnya biaya-biaya tambahan lain bagi perekonomian setempat.

\section{Metode}

Penelitian ini adalah penelitian deskriptif kualitatif. Teknik pengumpulan data berupa data primer yaitu observasi, wawancara, dokumentasi dan data sekunder berupa literatur serta dokumen. Teknik penentuan informan menggunakan snowball sampling. Teknik analisis data penelitian ini menggunakan analisis data model Miles and Huberman yaitu reduksi data, penyajian data, dan penarikan kesimpulan. Adapun teknik pemeriksaan keabsahan data menggunakan metode triangulasi yaitu sumber dan teknik.

\section{Hasil dan Pembahasan}

Pengelolaan wisata berbasis Communitybased Tourism di objek wisata Kampung Blekok

Pengelolaan wisata berbasis community-based tourism di objek wisata Kampung Blekok ditunjukkan pada Gambar 1. Berdasarkan Gambar 1 masyarakat berperan di semua lini pembangunan baik sebagai perencana, investor, pelaksana, pengelola, pemantau maupun evaluator yang menjadikannya sebagai pelaku utama dalam pengembangan community-based tourism. Berdasarkan hasil penelitian terdapat beberapa stakeholders dalam pengelolaan wisata yaitu Pemerintah Daerah, Dinas Lingkungan Hidup, Pemerintah Desa Klatakan dan Masyarakat. Adapun penerapan Community-based Tourism di Wisata Kampung Blekok antara lain:

\section{a. Tahap Perencanaan}

Pada tahap awal perencanaan wisata Kampung Blekok keterlibatan masyarakat dalam perencanaan dilakukan melalui proses sosialisasi. Proses perencanaan tidak hanya dilakukan pada awal pembangunan tetapi juga setelah pembangunan. Perencanaan ini membahas tentang program-program yang akan dilaksanakan untuk ke depannya. Perencanaan program dalam pengelolaan wisata dilakukan dengan koordinasi antara pihak Dinas Lingkungan Hidup, Kepala Desa serta Pokdarwis.

\section{b. Tahap Pelaksanaan}

Untuk pelaksanaan dalam pengelolaan wisata ini melibatkan masyarakat sekitar terutama didominasi oleh anggota Pokdarwis Kampung Blekok. Sebagian besar keseluruhan pelaksanaan program sudah ada pelibatan masyarakat, namun dalam pelaksanaannya belum optimal. Dalam setiap perencanaan tidak semua program dapat berjalan sesuai harapan. Hal ini dipengaruhi 


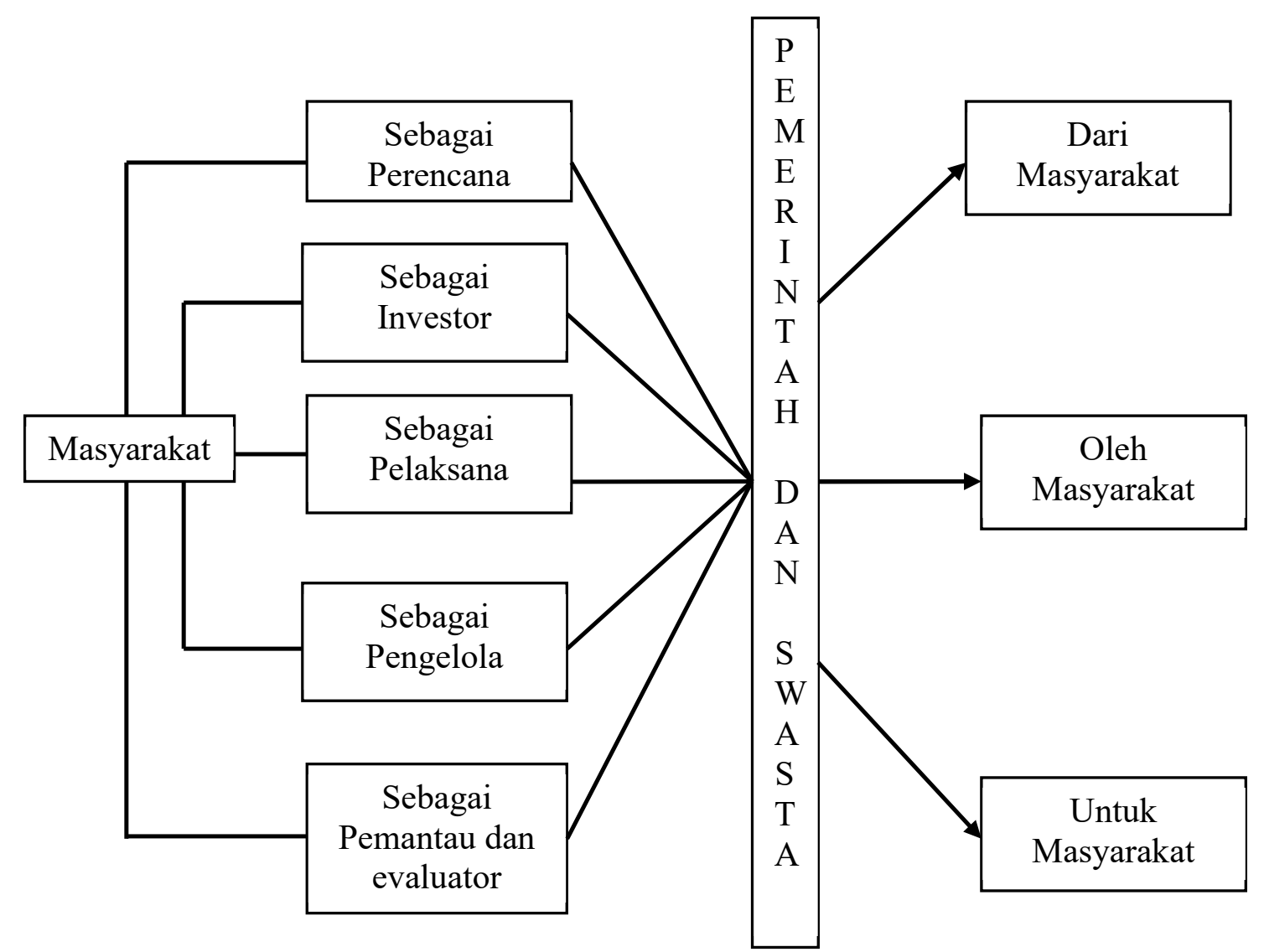

Gambar 1. Pola pengembangan pariwisata

beberapa hal yaitu peran serta dan kemandirian masyarakat.

\section{c. Tahap Pengelolaan}

Pengelolaan wisata Kampung Blekok dikelola oleh kelompok sadar wisata yang berasal dari masyarakat sekitar wisata. Selain itu, wisata ini juga dinaungi oleh Dinas Lingkungan Hidup Kabupaten Situbondo dikarenakan wisata ini merupakan leading sector dari Dinas Lingkungan Hidup. Untuk kegiatan operasional dalam pengelolaan wisata Kampung Blekok direkrut dari masyarakat sekitar. Kegiatan operasional terdiri dari 8 orang pekerja yang bertugas sebagai petugas parkir roda dua dan roda empat, penjaga tiket, dan penjaringan tiket. Sistem pekerjaan dilakukan dengan sistem shift yaitu 2 shift yaitu shift pagi dan shift siang. Shift pagi dimulai dari jam $06.00 \mathrm{WIB}$ - 12.00 WIB dan shift siang dimulai pukul $12.00 \mathrm{WIB}-18.00 \mathrm{WIB}$. Untuk upah pekerja perbulan yaitu $\mathrm{Rp} 400.000,00$ dialokasikan dari pendapatan Pokdarwis.

d. Tahap pengawasan
Tahap pengawasan dilakukan oleh Dinas Lingkungan Hidup. Untuk keterlibatan masayarakat dalam pengawasan hanya pelaporan kepada Dinas Lingkungan Hidup ketika terjadi penyelewenganpenyelewengan di wisata Kampung Blekok.

e. Tahap evaluasi

Kegiatan evaluasi didominasi oleh Dinas Lingkungan Hidup. Dalam tahapan ini juga terdapat pelibatan masyarakat yaitu oleh anggota Pokdarwis. Rapat evaluasi merupakan salah satu kegiatan dari Pokdarwis. Rapat evaluasi dilakukan minimal 1 bulan 1 kali. Rapat evaluasi ini membahas tentang permasalahan tentang Kelompok Sadar Wisata dan pengelolaan wisata.

Dermatoto (2013) menjelaskan usaha pembangunan pariwisata berbasis masyarakat pada saat ini mengalami banyak kendala yang antara lain tercermin pada berbagai program dan kegiatan yang bersifat top-down yang berakibat pada kurangnya respon, antusiasme serta keterlibatan 
masyarakat dalam pengelolaan dan pengembangan aset-aset wisata yang terdapat di wilayah mereka. Berdasarkan hasil penelitian berikut penerapan Communitybased Tourism dalam pengelolaan di objek wisata Kampung Blekok antara lain:

a. Manajemen Kelompok Sadar Wisata

Keberhasilan pengelolaan wisata Kampung Blekok ditentukan oleh pihak-pihak yang mengelolanya. Salah satu pihak yang memiliki peranan besar dalam pengelolaan yaitu Pokdarwis Kampung Blekok. Sebelum menginjak pada community-based tourism pada seluruh masyarakat Kampung Pesisir Timur perlu ada perubahan dalam manajemen Kelompok Sadar Wisata. Kelompok Sadar Wisata Wisata Kampung Blekok masih perlu beberapa perubahan terutama pada kekompakan, kedisiplinan dan keikutsertaan serta kemandirian seluruh anggota baik dalam perencanaaan, pelaksanaan, pengelolaan, pengawasan dan evaluasi wisata Kampung Blekok. Penguatan manajemen Pokdarwis dapat dijadikan acuan untuk pengoptimalan penerapan community-based tourism ke depannya. Terutama dalam keikutsertaan masyarakat sekitar dalam kegiatan pengelolaan Wisata Kampung Blekok.

\section{b. Pengembangan SDM}

Penambahan penerapan terkait Community-based tourism yang juga harus dilakukan yaitu pengembangan sumber daya manusia. Hal ini dimaksudkan untuk meningkatkan partisipasi masyarakat sekitar. Contoh nyata dapat dilakukan secara rutin dapat berupa sosialisasi, pelatihan maupun seminar. Hal tersebut sangat dibutuhkan untuk ke depannya.

c. Ramah tamah penduduk lokal.

Wisata ini berada di area penduduk Desa Klatakan yang mana dari jalan masuk hingga menuju lokasi wisata melewati rumah penduduk. Penerapan ramah tamah penduduk tidak hanya berlaku bagi pengelola saja, namun juga dari masyarakat sekitar. Hal ini untuk memberikan kenyamanan kepada pengunjung serta memberikan kepuasan pelayanan dalam pengelolaan wisata Kampung Blekok.

d. Pembentukan komunitas pengrajin
Kerajinan merupakan budaya lokal dari masyarakat sekitar area wisata Kampung Blekok. Pembuatan komunitas dilakukan dengan pengumpulan anggota dari masyarakat. Selain untuk mempererat kebersamaan, dapat digunakan sebagai media memperkenalkan dan membranding kerajinan khas Kampung Blekok di kota lain.

Didasarkan dari pemaparan di atas penerapan community-based tourism dalam pengelolaan ke depan di objek wisata Kampung Blekok dari peneliti antara lain sebagai berikut:

\section{a. Adanya kegiatan capacity building untuk masyarakat dan stakeholders}

Capacity building dapat dilakukan dalam bentuk pelatihan, training skill, kompetensi dan sertifikasi terutama di bidang pariwisata seperti pengetahuan umum objek wisata, pengelolaan objek wisata, dampak pariwisata, pelayanan pariwisata. Kegiatan ini dapat dilakukan dengan melakukan koordinasi dengan pemerintah daerah selaku fasilitator untuk mendatangkan narasumber sebagai upaya untuk meningkatkan pengetahuan dan wawasan masyarakat tentang objek wisata.

b. Meningkatkan pemberdayaan masyarakat lokal

Untuk kegiatan ini dapat dilakukan dengan mendorong peran aktif masyarakat dengan memberikan ruang dan tanggung jawab lebih besar kepada masyarakat. Peningkatan pemberdayaan masyarakat lokal mulai dari tahap perencanaan, pelaksanan, pengelolaan, pengawasan serta evaluasi. Dalam pemberdayaan masyarakat ini masyarakat lebih memiliki banyak akses atas sumber daya yang dimiliki serta ikut terlibat dalam pengambilan keputusan dalam pembangunan kepariwisataan.

\section{c. Penentuan carrying capacity dan conservation tax}

Suansri (2003) menjelaskan aspek utama dalam pengembangan community-based tourism adalah dimensi lingkungan yang di dalamnya terdapat mempelajari carrying capacity. Mengingat wisata ini juga merupakan area konservasi mangrove dan burung air serta area perumahan penduduk. 
Hal ini diperlukan agar pengelolaan wisata terus berjalan dengan baik tanpa merusak lingkungan wisata itu sendiri. Selain itu pemberlakuan conservation tax juga perlu diperlukan untuk menjaga kelstarian alam area wisata.

\section{d. Meningkatkan koordinasi dan kerja sama dengan stakeholders}

Koordinasi dan kerja sama antar stakeholders sangat diperlukan dalam setiap tahap pembangunan pariwisata baik perencanaan, pelaksanaan, pengelolaan, pengawasan maupun evaluasi. Untuk ke depannya pengelolaan wisata Kampung Blekok diperlukan adanya persetujuan antar semua pihak agar pengelolaaan wisata Kampung Blekok dapat berjalan dengan baik.

Cara peningkatan ekonomi masyarakat sesuai dengan konsep Community-based Tourism

Penerapan community-based tourism harus berkesesuaian dengan tujuan pariwisata berkelanjutan. Menurut Gortazar, et al (1999) menambahkan bahwa pariwisata berkelanjutan mempunyai penekanan khusus pada tiga hal. Salah satunya yaitu pemberdayaan masyarakat lokal untuk mempertinggi kehidupan sosial dan budaya guna meningkatkan kualitas dan standart hidup masyarakat lokal. Aspek utama dalam pengembangan community-based tourism adalah dimensi ekonomi yang menyatakan yaitu timbulnya pendapatan masyarakat lokal dari sektor pariwisata (Suansri, 2003). Didasarkan hal tersebut juga berlaku dalam pengelolaan Wisata Kampung Blekok. Adapun beberapa cara untuk peningkatan ekonomi masyarakat sesuai dengan konsep community-based tourism antara lain sebagai berikut:

a. Event melibatkan masyarakat sekitar.

Event merupakan upaya yang dapat dilakukan untuk peningkatan ekonomi masyarakat. Sudah terdapat beberapa event yang dilakukan di wisata Kampung Blekok yang melibatkan masyarakat sekitar. Event ini ada yang dilakukan secara rutin dan ada pula yang tidak. Event ini dikemas dengan pelibatan seluruh masyarakat serta memberikan peningkatan ekonomi masyarakat. Untuk ke depannya ini merupakan cara yang harus dilakukan yakni pengadaan event-event baru yang melibatkan masyarakat serta memberikan peningkatan ekonomi masyarakat. Berikut contoh event yang dilakukan di Kampung Blekok yaitu Festival Jejen Lambek dan lomba foto.

b. Mempertahankan program bank sampah

Bank sampah merupakan salah satu cara yang dilakukan untuk peningkatan ekonomi yang sudah dilakukan oleh masyarakat sekitar wisata Kampung Blekok. Selain untuk kebersihan, kelestarian lingkungan dan penyelesaian masalah sampah plastik di area wisata dan rumah penduduk. Cara kerja bank sampah yaitu mengambil sampah masyarakat baik masyarakat maupun pengunjung untuk di jual ke bank sampah. Kemudian di jual ke pengepul dengan harga Rp 2500,00/Kg. Setiap warga yang menjual sampah ke bank sampah dibayar dengan sistem ditabung dan hasilnya diambil pada saat lebaran.

\section{c. Kerja sama dengan pihak ketiga}

Pembangunan tempat atau bangunan membutuhkan dana yang besar. Pendanaan ini tidak bisa didapatkan dari pendapatan wisata, namun juga diperlukan kerja sama dengan pihak ketiga. Kerjasama dilakukan sebagai cara peningkatan ekonomi masyarakat wisata Kampung Blekok. Kerja sama ini dapat berupa CSR ataupun bantuan Cuma-Cuma dari Bank BRI dan PT POMI. Adapun bantuan pihak ketiga yang sudah diterima wisata Kampung Blekok yaitu: pembangunan 30 unit kandang sapi, pembangunan warung dan art shop, dan bantuan bibit sayuran. Ada beberapa harapan masyarakat yang masih belum berjalan seperti: pengadaan etalase untuk menjual kerajinan di depan rumah setiap masyarakat yang bekerja sebagai pengrajin, pembuatan stand sendiri untuk mangrove dan untuk pembuatan pupuk. Untuk ke depannya cara ini dapat dilakukan sebagai cara untuk menfasilitasi masyarakat dalam peningkatan ekonomi.

Didasarkan dari pemaparan di atas cara yang harus dilakukan untuk peningkatan ekonomi masyarakat sesuai dengan konsep community-based tourism dari peneliti yaitu pengelolaan wisata Kampung Blekok, pembentukan ekonomi kreatif dan pengembangan desa industri mandiri. 
Dampak ekonomi dan penanggulangan dampak negatif sesuai dengan CBT

Pengelolaan wisata berbasis communitybased tourism merupakan pengelolaan wisata berkelanjutan. Salah satu penekanan khusus dalam pariwisata berkelanjutan yaitu pengurangan dampak-dampak negatif yang ditimbulkan sehubungan dengan pengembangan pariwisata. Berikut Dampak ekonomi yang timbul di objek wisata Kampung Blekok dan cara menanggulangi dampak negatif sesuai dengan communitybased tourism.

Perkembangan pariwisata di suatu daerah akan menimbulkan dampak. Dampak merupakan perubahan-perubahan yang terjadi antara sebelum dan sesudah adanya wisata. Berikut adalah dampak positif ekonomi yang timbul di wisata Kampung Blekok antara lain:

a. Terbukanya lapangan kerja baru

Adanya pembangunan pariwisata akan menimbulkan suatu dampak. Salah satu dampak positif yaitu terbukanya lapangan kerja baru. Lapangan pekerjaan tidak hanya sebatas pada pengelolaan wisata saja, namun memberikan peluang bagi masyarakat sekitar area wisata untuk membuka usaha baik makanan, minuman maupun kerajinan.

b. Meningkatkan pendapatan

Adapun dampak positif adanya wisata Kampung Blekok adalah meningkatkan pendapatan. Peningkatan pendapatan ini dirasakan oleh Pemerintah Daerah Kabupaten Situbondo, Desa Klatakan dan Masyarakat. Pendapatan ini diperoleh atas hasil persentase dari total pendapatan yaitu $45 \%$ untuk pemerintah daerah, $25 \%$ untuk desa dan $30 \%$ untuk Pokdarwis. Peningkatan pendapatan masyarakat juga didapat dari adanya masyarakat yang berjualan dan menjadi pengelola wisata Kampung Blekok.

c. Pemanfaatan fasilitas pariwisata oleh masyarakat lokal

Dampak positif adanya wisata lainnya yaitu pemanfaatan fasilitas pariwisata oleh masyarakat lokal. Terdapat fasilitas warung yang mulai dimanfaatkan oleh masyarakat sebagai tempat untuk berjualan dan art shop dimanfaatkan oleh masyarakat sebagai tempat penitipan dari berbagai hasil kerajinan untuk dijual kepada pengunjung.

d. Membantu menanggung beban pembangunan sarana dan prasarana

Dampak positif setelah adanya wisata yaitu membantu menanggung beban pembangunan sarana dan prasarana. Pengembangan pariwisata mendorong seluruh elemen masyarakat untuk menyediakan sarana dan prasarana yang memadai untuk kepuasan pengunjung.

\section{e. multiplier effect}

Muliplier effect sebagai salah satu kegiatan ekonomi yang diharapkan dapat meningkatkan pendapatan sekitar. Jika seorang wisatawan mengeluarkan sejumlah uang tersebut juga akan menjadi pendapatan bagi penerimanya. Setiap wisatawan yang datang dan membeli satu hasil kerajinan yang dijual maka dampaknya juga dirasakan oleh penjual kayu sebagai bahan baku dari kerajinan kayu tersebut. Hal ini dikarenakan bahan baku kayu berasal dari daerah lain serta pihak lain.

Berikut adalah dampak negatif ekonomi yang timbul di wisata Kampung Blekok antara lain:

a. Waktu pengembalian modal investasi tidak pasti

Sifat pariwisata yang musiman ini mengakibatkan pendapatan juga fluktuatif. Hal ini juga berlaku untuk wisata Kampung Blekok. Konsekuensinya, pengembalian modal investasi tidak selalu sesuai dengan waktu yang telah diperhitungkan.

b. Adanya keinginan untuk mendapat keuntungan secara individual

Belum meratanya pendapatan penduduk mengakibatkan adanya keinginan individu untuk mendapat keuntungan secara pribadi. Contoh dulu sebelum penertiban terkait parkir ada saja penduduk yang mengambil uang secara pribadi dan tidak disetorkan kepada bagian tiket. Hal ini jika secara terus-menerus dilakukan akan mengakibatkan penurunan pendapatan wisata. 
Untuk penanggulangan dampak negatif dilakukan dengan evaluasi atas terjadinya dampak dan meminimalisir adanya dampak negatif dengan mempelajari hal-hal apa saja yang menimbulkan dampak tersebut terjadi untuk mempermudah problem solvingnya.

Didasarkan dari pemaparan di atas cara yang harus dilakukan untuk menanggulagi dampak negatif sesuai dengan konsep community-based tourism dari peneliti antara lain sebagai berikut:

\section{a. Pemerataan pendapatan penduduk}

Pemerataan pendapatan penduduk dengan melaksanakan berbagai cara sebagai upaya peningkatan ekonomi masyarakt sehingga tidak terjadi lagi keinginan untuk menguntungkan diri sendiri. Selain itu tingkat pengawasan pihak pengelola terutama masyarakat dalam mengawasi pemasukan dan pengeluaran dari pendapatan wisata perlu lebih ditingkatkan. Pembuatan sanksi-sanksi tertulis agar masyarakat lebih taat dan peduli atas wisata Kampung Blekok.

\section{b. Menentukan target pendapatan}

Guna menanggulangi sifat wisatawan yang musiman yang harus dilakukan yaitu lebih meningkatkan potensi dan produk wisata, menentukan target pasar dan jumlah wisatawan yang datang sehingga target pendapatan untuk menutupi investasi yang besar dapat tercapai sesuai target yang telah dibuat. Hal ini juga memerlukan kerja sama dari seluruh stakeholders khusus pengelola dengan cara mempertahankan kualitas produk wisata serta service quality management dalam pelaksanaan pelayanan produk wisata.

\section{Kesimpulan dan Saran}

Penelitian ini menghasilkan tiga kesimpulan penting, yaitu: (1) Penerapan community-based tourism di wisata Kampung Blekok sudah dilakukan dalam beberapa aspek yaitu perencanaan, pelaksanaan, pengelolaan, pengawasan dan evaluasi. Dalam penerapan community-based tourism di Kampung Blekok masih belum optimal untuk itu masih diperlukan penambahan penerapan dengan konsep community-based tourism antara yaitu Manajemen Pokdarwis, Pengembangan Sumber Daya manusia,
Ramah tamah penduduk lokal, dan pembentukan komunitas pengrajin; (2) Cara yang harus dilakukan untuk peningkatan ekonomi masyarakat sesuai dengan konsep community-based tourism di wisata Kampung Blekok yaitu event melibatkan masyarakat, Mempertahankan program bank sampah dan Kerja sama dengan pihak ketiga; (3) Dampak ekonomi yang timbul di objek wisata dan cara menanggulagi dampak negatif sesuai dengan community-based tourism di wisata Kampung Blekok yaitu terbukanya lapangan pekerjaan peningkatan pendapatan, pemanfaatan fasilitas pariwisata oleh masyarakat lokal, membantu menanggung beban pembangunan sarana dan prasarana dan multiplier effect. Selain itu, untuk dampak negatif ekonomi yaitu waktu pengembalian modal investasi tidak pasti dan adanya keinginan untuk mendapat keuntungan secara individual. Untuk penanggulangan dampak negatif yang dapat dilakukan dengan evaluasi dan meminimalisir adanya dampak negatif sehingga pada saat dampak negatif tersebut muncul sudah terdapat problem solving.

Saran yang dapat diberikan bagi instansi terkait sebagai berikut: (1) Bagi Pemerintah Daerah perlu memberikan seminar, sosialisasi, pelatihan dan pendidikan kepada masyarakat sekitar untuk meningkatkan pengetahuan, wawasan, dan skill. Selain itu, Pemerintah harus melakukan upaya promosi wisata agar wisata di Kabupaten Situbondo dapat lebih dikenal oleh wisatawan. Bagi pemerintah Desa terus lakukan pengawasan dan pengontrolan atas wisata di Kampung Blekok agar pengelolaan wisata dapat berjalan dengan baik; (2) Bagi Kelompok Sadar Wisata Kampung Blekok diharapkan lebih meningkatkan kekompakan, kemandirian, keikutsertaan dan partisipasi dalam pengelolaan wisata Kampung Blekok. Lebih berperan aktif dalam pengelolaan mulai dari tahap perencanaan, investasi, pelaksanaan, pengelolaan dan evaluasi yang disesuaikan dengan konsep community-based tourism demi terwujudnya wisata berkelanjutan; (3) Bagi Masyarakat diharapkan mampu memanfaatkan adanya pembangunan wisata Kampung Blekok ini. Tingkatkan keinginan ikut serta dan ikut aktif dalam mengeluarkan pendapat, hadir dalam setiap tahap pengelolaan dari perencanaan, investasi, 
pelaksanaan, pengelolaan, pengawasan dan evaluasi.

\section{Referensi}

Demartoto, A. 2008. Strategi Pengembangan Obyek Wisata Pedesaan Oleh Pelaku Wisata di Kabupaten Boyolali [Laporan Penelitian]. Surakarta: Universitas Sebeleas Maret

Dermatoto, A. 2013. Pembangunan Pariwisata Berbasis Masyarakat. Surakarta: UNS Press

Gortazar, Luis dan Cripriano. 1999. Tourism and sustainable. France: International Scientific Council For Island Development

Pitana, I.G dan Diarta, I. K. S. 2009. Pengantar Ilmu Pariwisata. Yogyakarta: ANDI
Pitana, I. G. dan Gayatri, P. G. 2005. Sosiologi Pariwisata. Yogyakarta: ANDI

Sitaresmi, G. 2011. Analisis Potensi Wilayah Pesisir Untuk Pengembangan Pariwisata Di Kabupaten Rembang. Semarang: Universitas Negeri Semarang.

Suansri, P. 2003. Community-based Tourism Handbook. Thailand: REST Project [diunduh 28 Februari 2019]. Tersedia pada https://www. Mekongtourism.org

Sukadjo. 1997. Anatomi Pariwisata. Jakarta: PT Gramedia Pustaka Utama

Sunaryo, B. 2013. Kebijakan Pembangunan Destinasi Pariwisata Konsep dan Aplikasinya di Indonesia. Yogyakarta: Gava Media

Undang-Undang Republik Indonesia Nomor 10 Tahun 2009 Tentang Kepariwisataan

World Tourism Organization. 2002. Tourism Highlights 2002. Capitan Haya: Madrid 